\title{
Preventative and Curative Effects of Several Plant Derived Agents Against Powdery Mildew Disease of Okra
}

\author{
Moustafa Hemdan Ahmed MOHARAM ${ }^{1 *}$, Hazim Abd El-Rahman OBIADALLA ALI² \\ ${ }^{1}$ Sohag University, Faculty of Agriculture, Plant Pathology Department, El-Kawther, Sohag \\ 82786,Egypt; moharam@hotmail.com (*correspondingauthor) \\ ${ }^{2}$ Sohag University, Faculty of Agriculture, Horticulture Department, El-Kawther, Sohag 82786, Egypt
}

\begin{abstract}
The preventative and curative effects of some plant derived agents based on plant extracts or essential oils were studied at different concentrations against Erysiphe cichoracearum DC. ex Merat, the causal pathogen of okra powdery mildew by the detached leaf-disk and potted plants bioassays. Through detached leaf-disk assay, the highest mean preventative effect (97.74\%) was recorded by neem seed oil followed by jojoba oil (89.82\%) and extract of Rynoutria sachalinensis $(82.77 \%)$. Neem seed oil at 1\% was the most effective agent followed by jojoba oil and extract of $R$. sachalinensis at $1.5 \%$ and $2 \%$, respectively, where they suppressed E. cichoracearum completely. Potted plants assay revealed that neem seed oil, jojoba oil and extract of $R$. sachalinensis as well as the fungicide (active ingredient dinocap) showed higher preventative efficacy at all leaf olds treated after 7 and 14 days of inoculation as compared with extracts of henna and garlic. Moreover, the preventative efficacy partly remained apparent after 14 days of inoculation at all leaf olds tested. In field trials through 2010 and 2011 growing seasons, when the first symptoms of powdery mildew appeared naturally, 1.5\% jojoba oil, $2 \%$ extract of $R$. sachalinensis and $1 \%$ neem seed oil were sprayed individually twice on grown plants to evaluate their efficacy on controlling powdery mildew, growth and yield of okra. Resulted showed that neem seed oil was the most effective agent and highly decreased the disease severity to $29.92 \%$, recorded the highly curative effect (68.15\%) and also improved plant growth and pods yield.
\end{abstract}

Keywords: okra, powdery mildew, preventative and curative effects, plant derived agents

\section{Introduction}

Powdery mildew fungi represent one of the most widely distributed and destructive groups of plant pathogens worldwide (Braun et al., 2002), and cause a serious disease of many vegetable crops (Pernezny et al., 2002). The disease is occurring on cultivated okra (Abelmoschus esclentus L.) in governorates Upper of Egypt as well as other Geographical regions and causing severe losses in yield and pods quality (Derbalah et al., 2011). Powdery mildew disease of okra caused by the air-borne fungus Erysiphe cichoracearum DC. ex Merat., is clearly distinguished by the development of white powdery on leaf surfaces, stem, and pods. At present, use of fungicides as repeated applications and cultivars resistant or tolerant to powdery mildew are the main available two methods for disease control in crop production. However, both methods have their own limitations (Kiss, 2003). There are public attitudes and environmental concerns towards the use of fungicides (Belanger and Benyagoub, 1997; Whipps and Lumsden, 2001), as well as occurrence of new strains resistant to different fungicides (Moustafa et al., 1990; OBBien, 1994). Use resistant or tolerant cultivars have been developed in many crops, but it is also limited especially in vegetable crops (Kiss, 2003; Romero et al., 2007). For instance, in other important crops such as tomato and cucumber most cultivars available to growers worldwide are susceptible (Kiss et al., 2001; Kiss, 2003; Konstantindou-Doltisinis et al., 2006). All these constraints associated with the use of fungicides and resistant cultivars have led to search for alternative methods to control powdery mildew. Biological control based on the antagonism between microorganisms (Andrews, 1992; Cook and Baker, 1983) or inhibitory effect of plant derived agents on the pathogen (Konstantindou-Doltisinis et al., 2006; Rakhonde et al., 2011), is considered an alternative way to prevent or suppress powdery mildew on grown crops. For this propose, many successful attempts had been made to use the antagonists or their culture filtrates for controlling powdery mildew on okra and other crops (Alahakoon et al., 2010; Derbalah et al., 2011; Gilardi et al., 2008; Picton and Hummer, 2003; Romero et al., 2007; Scheurell and Mahaffee, 2000; Shailbala, 2011). However, these attempts have provided no promise of practical control to date (Kiss, 2003) especially for small scale-farmers in Egypt. Hence, use of plant derived materials has a good potential for the management of powdery mildews. Moreover, it is a relatively cheap, practical, safely and eco-friendly as compared with chemicals. As far as available of literature, no attempts have been done to suppress powdery mildew on okra using plant derived agents including plant extracts. Although, several researchers have reported the efficiency of plant extracts to suppress 
many plant pathogens including powdery mildew on other crops (El-Kazzaz et al., 2003; Hegazi and El-Kot, 2010; Konstantindou-Doltisinis et al., 2006; Liu et al., 2010; Rakhonde et al., 2011; Rettinassababady et al., 2000; Singh, 2008; Varma and Gandhi, 2007). Water extracts of Garlic and henna were effective and controlled the natural infection of powdery mildew on cucumber and zinnia with enhancing of plant growth (Hegazi and El-Kot, 2010; Morsy et al., 2009). Recently, number of plant derived agents based on plant extracts or essential oils derived from plants are widespread, available and marketable. Because these agents are generally expected to be favourable regarding toxicological and environmental properties, they do not have to be registered as pesticides in some countries and may be marketed as plant strengthening products. For instance, a formulated plant extract from the giant knotweed of Rynoutria sachalinensis) is registered in Germany as plant strengthener, known to induce resistance to powdery mildew caused by Sphaerotheca fuliginea on cucumber and achieved a disease reduction ranging from $42.2-64 \%$ (Konstantindou-Doltisinis et al., 2006). Other products, neem oil extracted from seeds of Azadirachta indica and jojoba oil extracted from Buxus chinensis are registered as fungicides in USA and Canada, respectively, and they are applied effectively to control powdery in cucurbits (Nuñez-Palenius et al., 2009). Information is very meagre on the effects of these commercial agents on powdery mildew, growth and yield of okra. Therefore, this study was planed to evaluate the efficacy of some plant derived argents in comparison with a conventional fungicide against the pathogen in greenhouse and field trials. Their influence on plant growth and pods yield was also studied.

\section{Materials and methods}

\section{Preparation of the pathogen inocula}

Powdery mildew-infected leaves of okra plants were collected at Experimental Farm, Faculty of Agriculture, Sohag University, Egypt. On the basis of morphological characteristics of the conidial stage the pathogen was identified as Erysiphe cichoracearum DC. ex Merat. (Alexopoulos et al., 1996; Boseewinket, 1980). In plastic pots $(30 \mathrm{~cm}$ in diameter), the pathogen was cultured on leaves of the susceptible okra cultivar ('Assiut') and then re-cultured every 4 weeks by tapping the powdery infected leaves over leaves 4-8 weeks old of grown plants. The pathogen was also maintained on leaves of okra plants grown in pots at $28^{\circ} \mathrm{C}$ (day) and $22^{\circ} \mathrm{C}$ (night) and $16 \mathrm{~h}$ light: $8 \mathrm{~h}$ dark photoperiod. The highly infected leaves were gently scraped to collect conidia and washed with sterile distillated water (SDW), then the spores were suspended in tubes and filtrated through sterilized cheese cloth (Jeong et al., 2007). The spore suspensions were determined by a hemocytometer and adjusted to concentration $1 \times 10^{5}$ conidia $\mathrm{ml}^{-1}$ for inoculating plants. Conidia suspensions can be prepared freshly and used only during $1 \mathrm{~h}$ at the same time of inoculation.

\section{Plant derived agents}

Five agents based on plant extracts and essential oils listed in Tab. (1) were used in this study. Liquid products of jojoba oil (JO), extract of Reynoutria sachalinensis (ER) and neem seed oil (NSO) were diluted with distillated water (DW) to obtain final concentrations $0.5,1,1.5,2,2.5$ and $3 \%$. Water extract of henna was prepared by macerating $3 \mathrm{~g}$ fresh powder in $100 \mathrm{ml} \mathrm{DW}$ in an electric blender for $2 \mathrm{~min}$ at room temperature and then left for $24 \mathrm{~h}$ at $4^{\circ} \mathrm{C}$. The macerate was centrifuged for $10 \mathrm{~min}$ at 10000 rpm and $4^{\circ} \mathrm{C}$, and then filtrated through filter paper. Water extract of garlic was prepared by stirring $3 \mathrm{~g}$ of the plant granules in $100 \mathrm{ml}$ heated DW $\left(50^{\circ} \mathrm{C}\right)$ for an hour, followed by centrifugation for $10 \mathrm{~min}$ at $10000 \mathrm{rpm}$ and $4^{\circ} \mathrm{C}$. The prepared plant extracts (stock conc. 3\%) were diluted to $0.5,1,1.5,2$ and $2.5 \%$ with DW.

\section{Bioefficacy of plant derived agents against E. cichoracear- um}

\section{In vitro detached leaf-disc bioassay}

The 2, 4, 6 and 8 weeks old leaves taken from diseasefree plants were detached and the leaf-discs $(1 \mathrm{~cm}$ in diameter) were obtained by punch (Cohen, 1993). The leaf disc was randomly used, 20 discs were emerged into each of tested plant derived agent (Tab. 1) at freshly prepared concentrations $0.5,1,1.5,2,2.5$ and $3 \%$ for 5 seconds and then placed adaxial side up on the filter paper soaked with a nutrient solution (950 mg $\mathrm{Ca}\left(\mathrm{NO}_{3}\right)_{2} \cdot 4 \mathrm{H}_{2} \mathrm{O} ; 810$ $\mathrm{mg} \mathrm{KNO} ; 500 \mathrm{mg} \mathrm{Mg} \mathrm{SO} .7 \mathrm{H}_{2} \mathrm{O} ; 155 \mathrm{mg} \mathrm{NH}_{4} \mathrm{H}_{2} \mathrm{PO}_{4}$; $3 \mathrm{mg} \mathrm{H} \mathrm{BO}_{3} ; 2 \mathrm{mg} \mathrm{Zn} \mathrm{SO} .7 \mathrm{H}_{2} \mathrm{O} ; 0.05 \mathrm{mg} \mathrm{Cu} \mathrm{SO} .{ }_{4}^{4}$ $\mathrm{H}_{2} \mathrm{O} ; 0.02 \mathrm{mg} \mathrm{NaMoO}_{4}$ and $25 \mu \mathrm{g} \mathrm{NaFeEDTA} \mathrm{L}{ }^{-1}$ of distillated water, Pramanik et al., 2000) in $10 \mathrm{~cm}$ Petri plates. Each plate contains 5 discs and 4 plates were used for each treatment. Leaf-discs soaked with DW and active ingredient dinocap (a chemical fungicide, diluted to $0.5,1,1.5,2$,

Tab. 1. List of plant derived agents based on plant extracts and essential oils used in this study

\begin{tabular}{ccc}
\hline Name of plant & Form & Manufacturer/Distributor \\
\hline Jojoba (active principle: oil extract of Buxus chinensis) & Liquid $^{*}$ & Lawin and garden products, INC, Fresno, Canada \\
Garlic (Allium satavium) & Granules $^{* *}$ & FUCHS edle Gewürze, Dissen, Germany \\
Henna (Lawsonia inermis) & Powder leaves $^{* *}$ & Organic Herbspices, Minia, Egypt \\
Giant knotweed (active principle: extract of Reynoutria sachalinensis) & Liquid $^{*}$ & KHH BioScience Inc. Raleigh, NC, USA \\
Neem (active principle: oil seed extract of Azadirachta indica) & Liquid $^{*}$ & Certis, L.L.C., Guilford Road, USA \\
\hline
\end{tabular}

Plant materials are recommended for the use in plant protection $\left(^{*}\right)$ or for pharmaceutical purposes $\left({ }^{* *}\right)$ 
78

2.5, and 3\%) was served as negative and positive controls, respectively. The plates of leaf-discs were left overnight and $10 \mu \mathrm{L}$ of the pathogen conidial suspension was placed onto the centre of the leaf-discs, which then incubated at $28^{\circ} \mathrm{C}$ (day) and $22^{\circ} \mathrm{C}$ (night) and $16 \mathrm{~h} \mathrm{light:} 8 \mathrm{~h}$ dark photoperiod for one week. Disease severity (DS) of powdery mildew was assessed as percentage of infected area using $0-3$ scale, where $0=$ no symptoms; $1=$ less than $30 \%$ of infected leaf-disc area; $2=$ more than $30 \%$ of infected leafdisc area; $3=$ powdery mildew colonies cover the whole leaf-disc. The percent of DS was calculated by the following formula (Fang, 1998). DS (\%) $=[\Sigma$ (The number of diseased leaves in the range $\times$ the disease range)/(Total leaves investigated $\times$ the highest range) $] \times 100$

The preventative effect $(\mathrm{PE})$ of plant derived agents was also calculated with the following formula (Fang, 1998):

$\mathrm{PE}(\%)=\left[\left(\mathrm{DS}_{\mathrm{C}}-\mathrm{DS}_{\mathrm{T}}\right) / \mathrm{DS}_{\mathrm{C}}\right] \times 100$

Where, $\mathrm{DS}_{\mathrm{C}}=$ disease severity of negative control, $\mathrm{DS}_{\mathrm{T}}=$ disease severity of the treatment

\section{Preventative and curative assays at potted plants}

The efficacy of plant derived agents against powdery mildew was also tested in greenhouse trials. Sterilized plastic pots were filled with $8 \mathrm{~kg}$ autoclaved sandy loam soil. Seeds of okra $c v$. 'Assiut' were disinfected by dipping in $2 \%$ sodium hypochlorite solution for 3 minutes, rinsed for 5 times with sterilized water and then left to air dry. Two seeds were sown in each pot, and 12 pots were used for each treatment in a randomized complete block design (RBD) with three replications. A total 24 plants were treated in each variant. Pots were irrigated when necessary. For preventative assay, leaves of grown okra plants at the 2, 4, 6 and 8 weeks old separately were sprayed with $1.5 \% \mathrm{JO}$, 2.5\% henna extract (HE), 2.5\% garlic extract (GE), 2\% ER and $1 \%$ NSO. Leaves sprayed with DW and $2 \%$ dinocap served as negative and positive controls, respectively. The treated leaves were inoculated with conidia suspension $\left(1 \times 10^{5}\right.$ conidia $\left.\mathrm{ml}^{-1}\right)$ by atomizer. The curative assay was performed in the same way to the preventative assay except leaves at the same ages were inoculated with conidia suspension, and $24 \mathrm{~h}$ later sprayed with each tested conc. of plant derived materials. The experiments were repeated twice throughout 2010 and 2011 growing seasons.

Disease severity was recorded 7 and 14 days after inoculation. The incidence of powdery mildew was evaluated visually on individual leaf as percentage of diseased area, using a scale reported by (Liang et al., 2005). Preventative effect or curative effect (CE) was measured as described above. The obtained data were statistically analyzed using Analysis of Variance (ANOVA) with the MSTAT-C program and the least significant difference (LSD) was used at 0.05 level of probability (Gomez and Gomez, 1984).

\section{Field trials}

Field trails were conducted during the summer 2010 and 2011 to prove the curative efficacy of these plant de- rived agents in comparison with dinocap against powdery mildew of okra. The experiment was laid in RBD with three replications. A healthy of okra $c v$. 'Assiut' was raised following the recommended cultivation practices. When the first symptoms of powdery mildew occurred naturally, $1.5 \% \mathrm{JO}, 2 \% \mathrm{ER}$ and $1 \% \mathrm{NSO}$ were sprayed on grown plants as described before. A second spray was applied 7 days later. Water and 2\% dinocap sprayed plots served as negative and positive controls, respectively. Observations on the disease incidence were recorded 14 days after the second spray and finally percent of DS and CE were calculated. Some growth parameters such as plant height (in $\mathrm{cm})$, number of branches/plant and fresh green pod yield per plant (weight of 20 harvesting times) were recorded 100 days after sowing. The obtained data were statistically analyzed as described before.

\section{Results and discussion}

\section{Detached leaf-disk bioassay of plant derived agents against E. cichoracearum}

In this study, leaf-disk bioassay is considered as primary step to decide the effect of plant derived agents against powdery mildew pathogen in vitro (Liu et al., 2010). Among the plant derived agents tested by detached leafdisk bioassay (Tab. 2), maximum mean of PE (97.74\%) was recorded in NSO which was significantly superior to all other agents and was similar to the activity of the positive control (dinocap). This was followed by JO $(89.82 \%)$ and ER (82.77\%). While minimum mean of PE (28.51\%) was recorded by HE. Garlic extract exhibited noticeable of PE with mean $38.42 \%$. Among all plant derived agents evaluated at different concentrations, NSO at $1 \%$ was the most effective agent followed by JO oil and ER at 1.5\% and $2 \%$, respectively, where they suppressed powdery mildew completely. With increasing the extract concentration of garlic and henna up to $2.5 \%$, the PE increased to 69.5 and $47.48 \%$, respectively, and then the PE significantly did not increase even 3\%. Both $R$. sachalinesis aqueous extract and Milsana (VP 1999) were found to inhibit conidia germination of Leveillula taurica, the causal pathogen of tomato powdery mildew, in vitro and in vivo bioassay by detached tomato leaf-disk (Konstantindou-Doltisinis et al., 2006). The obtained strongly preventative effect of the tested plant derived agents against $E$. cichoracearum maybe due to contain inhibitory compounds. Other investigators reported that plant extracts and essential oils contain antifungal compounds that can inhibit the growth of certain plant fungal pathogens (El-Kazzaz et al., 2003; Farag et al., 1989; Krishna Kishore and Pandy 2007; Scarito et al., 2007; Sheng et al., 2005; Zambonelli et al., 1996).

Effect of plant derived agents against okra powdery mildew in potted plants bioassay

Potted plants bioassay in greenhouse trail is indispensable because this easy is more similar to the real situa- 
Tab. 2. Preventative effect of plant derived agents tested at different concentrations against the okra powdery mildew in the detached leaf-disc bioassay

\begin{tabular}{|c|c|c|c|c|c|c|c|}
\hline \multirow{3}{*}{ Treatment } & \multicolumn{7}{|c|}{ PE (\%) } \\
\hline & \multicolumn{6}{|c|}{ Concentration (\%) } & \multirow{2}{*}{ Mean } \\
\hline & 0.5 & 1 & 1.5 & 2 & 2.5 & 3 & \\
\hline Jojoba oil & 62.64 & 76.29 & 100 & 100 & 100 & 100 & 89.82 \\
\hline Garlic extract & 5.10 & 13.58 & 20.35 & 50.86 & 69.50 & 71.18 & 38.42 \\
\hline Henna extract & 3.39 & 10.18 & 18.57 & 40.69 & 47.48 & 50.75 & 28.51 \\
\hline R. sachalinensis extract & 49.09 & 59.34 & 88.16 & 100 & 100 & 100 & 82.77 \\
\hline Neem seed oil & 86.46 & 100 & 100 & 100 & 100 & 100 & 97.74 \\
\hline Dinocap (positive control) & 93.46 & 96.67 & 98.30 & 100 & 100 & 100 & 98.57 \\
\hline DW (negative control) & 0.01 & 0.01 & 0.01 & 0.01 & 0.01 & 0.01 & 0.01 \\
\hline Mean & 42.87 & 50.86 & 60.77 & 70.22 & 73.85 & 74.56 & 62.26 \\
\hline
\end{tabular}

L.S.D. 0.05

Treatment $(\mathrm{T})=1.87$; Concentration $(\mathrm{C})=3.72 ; \mathrm{T} \times \mathrm{C}=4.56$

tion. NSO, JO and extract of ER as well as the fungicide, showed higher efficacy as compared with extract of henna and garlic in preventative assay at all leaf olds treated (2, 4, 6 and 8 weeks) of potted plants (Tab. 3a). NSO, JO and ER showed preventative efficacy with means of 99.67 , 98.85 and $94.95 \%$, respectively at 7 days after inoculation which were similar to the activity of positive control (97.79\%). Moreover, the preventative efficacy partly remained apparent after 14 days at all leaf olds with means PE of $97.88,93.83$ and $91.58 \%$, respectively. Extracts of henna and garlic exhibited noticeable preventative efficacy against powdery mildew at all leaf olds with means $\mathrm{PE}$ of (51.78 and 58.13\%) and (45.89 and 52.14\%) after 7 and 14 days of inoculation, respectively. In this experiment, some plant derived agents showed the same PE at all leaf olds treated (NSO, JO and ER) and some different effect (henna and garlic extract) between the two different assays used (detached leaf-disk and potted plants). These may be because the assay with leaf-disk was accomplished by soaking the leaf disks in the agent solution, while that with potted plants, the agent solution was sprayed on the leaves, the solution quantity absorbed by leaves may differ- ent between these two methods (Liu et al., 2010). Moreover, assay with leaf-disks was in cultural dishes which was a closed condition, while with potted plant method, it was an opened condition. Some agents (henna and garlic extracts) had the effect in the closed culture dished, may be due to the volatilization of the active compounds, may had no effect with the potted plants. These may explain some differences between two assays.

NSO showed higher curative efficacy than dinocap at all leaf olds after 7 and 14 days of inoculation with means CE of 70.58 and $61.86 \%$, respectively (Tab. 3b). While JO recorded significantly curative efficacy at all leaf olds with means CE of 59.24 and $64.47 \%$ after 7 and 14 days of inoculation, respectively. On the other hand, ER exhibited considerable CE all leaf olds with means (37.5 and $24.94 \%$ after 7 and 14 days of inoculation, respectively). Konstantindou-Doltisinis et al. (2006) reported that aqueous extract of $R$. sachalinensis and its product Milsana was equally effective to wettable sulphur, its effect was rather preventative than curative against powdery mildew of tomato and achieved a disease reduction ranging from 42.2-64\%. Moreover, of all tested agents, the curative effi-

Tab. 3a. The preventative effect of tested plant derived agents against okra powdery mildew under artificial infection in greenhouse

\begin{tabular}{|c|c|c|c|c|c|c|c|c|c|c|}
\hline \multirow{3}{*}{ Treatment } & \multicolumn{10}{|c|}{ PE\% determined } \\
\hline & \multicolumn{5}{|c|}{7 days after inoculation of } & \multicolumn{5}{|c|}{14 days after inoculation of } \\
\hline & $\begin{array}{l}\text { 2-weeks } \\
\text { old leaves }\end{array}$ & $\begin{array}{l}\text { 4-weeks } \\
\text { old leaves }\end{array}$ & $\begin{array}{l}\text { 6-weeks } \\
\text { old leaves }\end{array}$ & $\begin{array}{l}\text { 8-weeks } \\
\text { old leaves }\end{array}$ & Mean & $\begin{array}{l}\text { 2-weeks } \\
\text { old leaves }\end{array}$ & $\begin{array}{l}\text { 4-weeks } \\
\text { old leaves }\end{array}$ & $\begin{array}{l}\text { 6-weeks } \\
\text { old leaves }\end{array}$ & $\begin{array}{l}\text { 8-weeks } \\
\text { old leaves }\end{array}$ & Mean \\
\hline JO $1.5 \%$ & $99.14^{*}$ & 98.30 & 99.07 & 98.90 & 98.85 & 90.67 & 93.33 & 94.82 & 96.49 & 93.83 \\
\hline GE $2.5 \%$ & 60.34 & 57.62 & 57.44 & 57.14 & 58.13 & 52.53 & 51.67 & 51.72 & 52.63 & 52.14 \\
\hline HE $2 \%$ & 55.17 & 52.53 & 50.00 & 49.45 & 51.78 & 44.90 & 50.00 & 43.96 & 44.73 & 45.89 \\
\hline ER 2\% & 97.41 & 91.52 & 92.58 & 96.70 & 94.55 & 89.93 & 90.83 & 90.81 & 94.73 & 91.58 \\
\hline NSO $1 \%$ & 100 & 100 & 99.07 & 100 & 99.67 & 96.61 & 97.50 & 98.27 & 99.12 & 97.88 \\
\hline$\left(\right.$ Negative control $\left.^{* *}\right)$ & 0.01 & 0.01 & 0.01 & 0.01 & 0.01 & 0.01 & 0.01 & 0.01 & 0.01 & 0.01 \\
\hline (Positive control $^{* * *}$ ) & 98.28 & 97.45 & 97.22 & 97.79 & 97.68 & 94.07 & 92.50 & 95.68 & 95.61 & 94.47 \\
\hline L.S.D. 0.05 & 2.58 & 2.34 & 2.21 & 2.11 & 2.03 & 1.98 & 1.91 & 1.87 & 1.84 & 1.81 \\
\hline
\end{tabular}

${ }^{*}$ The values are the mean of treated 48 plants represented 3 replicates in 2010 and 2011 growing seasons. ${ }^{* *}$ Plant sprayed with DW. ${ }^{* * *}$ Plant sprayed with dinocap 
80

Tab. 3b. The curative effect of tested plant derived agents against okra powdery mildew under artificial infection in greenhouse

\begin{tabular}{|c|c|c|c|c|c|c|c|c|c|c|}
\hline \multirow{3}{*}{ Treatment } & \multicolumn{10}{|c|}{ CE\% determined } \\
\hline & \multicolumn{5}{|c|}{7 days after inoculation of } & \multicolumn{5}{|c|}{14 days after inoculation of } \\
\hline & $\begin{array}{l}\text { 2-weeks } \\
\text { old leaves }\end{array}$ & $\begin{array}{l}\text { 4-weeks } \\
\text { old leaves }\end{array}$ & $\begin{array}{l}\text { 6-weeks } \\
\text { old leaves }\end{array}$ & $\begin{array}{l}\text { 8-weeks } \\
\text { old leaves }\end{array}$ & Mean & $\begin{array}{l}\text { 2-weeks } \\
\text { old leaves }\end{array}$ & $\begin{array}{l}\text { 4-weeks } \\
\text { old leaves }\end{array}$ & $\begin{array}{l}\text { 6-weeks } \\
\text { old leaves }\end{array}$ & $\begin{array}{l}\text { 8-weeks } \\
\text { old leaves }\end{array}$ & Mean \\
\hline JO $1.5 \%$ & $65.25^{\circ}$ & 63.44 & 57.27 & 51.03 & 59.24 & 51.67 & 40.67 & 54.86 & 38.67 & 46.47 \\
\hline GE $2.5 \%$ & 22.88 & 25.86 & 12.73 & 10.41 & 17.97 & 15.00 & 13.35 & 10.61 & 5.67 & 11.16 \\
\hline HE 2\% & 18.30 & 17.24 & 6.37 & 1.87 & 10.95 & 10.00 & 3.39 & 4.42 & 0.90 & 4.68 \\
\hline ER 2\% & 54.23 & 31.03 & 29.99 & 23.96 & 34.80 & 37.50 & 20.33 & 22.13 & 19.81 & 24.94 \\
\hline NSO $1 \%$ & 69.15 & 69.49 & 71.82 & 71.87 & 70.58 & 58.33 & 60.17 & 61.05 & 67.92 & 61.86 \\
\hline$\left(\right.$ Negative control $\left.{ }^{* *}\right)$ & 0.01 & 0.01 & 0.01 & 0.01 & 0.01 & 0.01 & 0.01 & 0.01 & 0.01 & 0.01 \\
\hline$\left(\right.$ Positive control $\left.^{* * *}\right)$ & 67.18 & 63.21 & 58.33 & 52.53 & 60.31 & 61.67 & 58.48 & 51.21 & 44.90 & 54.07 \\
\hline L.S.D. 0.05 & 3.14 & 3.08 & 2.96 & 2.83 & 3.11 & 2.32 & 2.21 & 2.63 & 1.97 & 2.03 \\
\hline
\end{tabular}

* The values are the mean of treated 48 plants represented 3 replicates in 2010 and 2011 growing seasons. ${ }^{* *}$ Plant sprayed with DW. ${ }^{* * *}$ Plant sprayed with dinocap

cacy partly decreased apparent after 14 days at all leaf olds treated (Tab. 3b). It is normally considered that the plant derived agents based on plant extract or essential oils are a mixture of the secondary metabolism (Liu et al., 2010), the importance of these agents is not only for the inhibitory effect on the pathogen, but in way due to their ability to induce host resistance through increase the activity of many enzymes which playing a defence role against invading pathogens (Caruso et al., 2001; Nawar and Kuti, 2003). The compounds responsible for the preventative and curative effects could be isolate from these agents in relation to host resistance and further study later.

Two effects, preventative and curative were studied in vivo assays with potted plants at 2, 4, 6 and 8 weeks old leaves treated. Results of these bioassays may help the trail in the field, for the agents possessing the PE may be applied before or the same time as the appearance of the powdery mildew symptom, while for other one with CE, can be applied after the appearance of the symptoms.

Field trails to evaluate the effect of plant derived agents on powdery mildew, growth and yield of okra

In this experiment, the agents NSO, JO and ER which were demonstrated to have the two effects in the potted plants bioassay, they could be use to apply immediately after the first appearance of the symptoms, and prevent the development of the symptoms under field conditions.
NSO, JO and ER at conc. 1, 1.5 and 2\%, respectively, were sprayed twice on grown plants to investigate their effect on powdery mildew, growth and yield of okra. Results represented in (Tab. 4) showed that NSO was the most effective agent and highly decreased the DS of okra powdery mildew to 31.33 and $28.5 \%$ in 2010 and 2011 growing seasons, respectively under natural infection as compared with the other agents. NSO recorded also the highly CE against powdery mildew with mean of $68.15 \%$ and it seemed to be similar to the activity of positive control (67.60\%). While JO decreased significantly the mean of DS to $40.84 \%$ and recorded CE with mean $56.64 \%$. ER showed the lowest efficacy in controlling the disease and

Tab. 4. Efficacy of tested plant derived agents against okra powdery mildew under natural infection in field through 2010 and 2011 seasons

\begin{tabular}{ccccccc}
\hline \multirow{2}{*}{ Treatment } & \multicolumn{3}{c}{ DS\% } & \multicolumn{3}{c}{ CE\% } \\
\cline { 2 - 7 } & 2010 & 2011 & Mean & 2010 & 2011 & Mean \\
\hline JO 1.5\% & 42.50 & 39.17 & 40.84 & 56.03 & 57.25 & 56.64 \\
ER 2\% & 74.17 & 60.83 & 67.5 & 23.27 & 28.32 & 25.79 \\
NSO 1\% & 31.33 & 28.5 & 29.92 & 67.59 & 68.71 & 68.15 \\
(Negative control*) $\left.^{*}\right)$ & 96.67 & 91.67 & 94.17 & 0.01 & 0.01 & 0.01 \\
(Positive control $^{* * *}$ ) & 31.67 & 29.17 & 30.42 & 67.23 & 68.17 & 67.60 \\
L.S.D. 0.05 & 1.67 & 1.32 & 1.42 & 1.51 & 1.54 & 1.54 \\
\hline
\end{tabular}

${ }^{*}$ The values are the mean of 120 plants represented 3 replications; ${ }^{* *}$ Plant sprayed with DW; ${ }^{* * *}$ Plant sprayed with dinocap

Tab. 5. Effect of plant derived agents on some growth parameters and fresh pod yield of okra

\begin{tabular}{cccccc}
\hline Treatment & $\begin{array}{c}\text { Plant height } \\
(\mathrm{cm})\end{array}$ & $\begin{array}{c}\text { Number of } \\
\text { branches/plant }\end{array}$ & $\begin{array}{c}\text { Number of } \\
\text { leaves/plant }\end{array}$ & $\begin{array}{c}\text { Number of } \\
\text { pods/plant }\end{array}$ & $\begin{array}{c}\text { Fresh pod } \\
\text { yield/plant }(\mathrm{g})\end{array}$ \\
\hline JO 1.5\% & $123.22^{* *}$ & 3.5 & 26.6 & 26 & 177.54 \\
ER 2\% & 115.21 & 3.4 & 22.3 & 20 & 138.28 \\
NSO 1\% & 139.56 & 3.9 & 42.2 & 44 & 276.32 \\
(Negative control $^{* * *}$ ) & 97.69 & 3.2 & 16.7 & 17 & 103.76 \\
(Positive contro $^{* * *}$ ) & 128.27 & 3.8 & 34.5 & 37 & 232.36 \\
\hline L.S.D. 0.05 & 5.03 & 0.1 & 2.7 & 1.7 & 12.23 \\
\hline
\end{tabular}

${ }^{*}=$ Mean of pods weight of 20 harvesting times per plant. ${ }^{* *}$ The values are the mean of 120 plants represented 3 replications in each 2010 and 2011 growing seasons.

*** Plant sprayed with DW. ${ }^{* * * *}$ Plant sprayed with dinocap 
recorded CE with mean $25.79 \%$. The inhibitory effect of neem and jojoba oils and a product extracted from $R$. sachalinensis on E. cichoracearum and L. taurica of other crops (Alahakoon et al., 2010; Konstantindou-Doltisinis et al., 2006; Nuñez-Palenius et al., 2009; Rettinassababady et al., 2000; Singh, 2008) have been reported earlier which are in agreement with the present findings.

The effect of plant derived agents on biometric parameters such as plant height, number of branches, leaves and pods per plant and fresh pod yield/ plant were analysed statistically and compared with that of dinocap (positive control). The results of these biometric observations for the mean of two years are presented in Tab. 5. The results showed that variation among the means of all treatments were found to be statically significant at $5 \%$ level. Spraying okra plants twice with $1 \% \mathrm{NSO}$ was the most effective agent and highly increased the growth parameters of plant height, number of branches, leaves and pods per plant and fresh pod yield/plant as compared to the negative and positive controls. While JO and ER significantly increased the growth and pods yield of okra plant as compared to the negative control. Hegazi and El-Kot (2010) reported the efficiency of some other essential oils on controlling powdery mildew of zinnia caused by E. cichoracearum and enhancement plant vegetative growth.

\section{Conclusions}

It can be concluded from the results of this study that the commercial products of plant derived agents based on plant extracts or essential oils have proved preventative and curative effects against powdery mildew when they tested by detached leaf-disk and potted plants bioassays. NSO exhibited the most effective ones and was similar to the activity of the conventional fungicide (active ingredient dinocap). It improved plant growth and increased also pods yield under filed conditions. The results provide for a reasonable basis of a possible utilization of plant derived agents as a safe, eco-friendly and alternative method to fungicides for controlling powdery mildew of okra plants.

\section{Acknowledgement}

Authors are thankful to all members of Experimental Farm, Faculty of Agriculture, Sohag University for financial support to carry out the research work.

\section{References}

Alahakoon PW, Jayawardene NH, Madushani KC, Nilmini RK (2010). Introduction of bio-fungicides for controlling powdery mildew disease of Rambutan. Proc of the Internat For and Environ Symp, Univ of Sri Jayewardenepura, Sri Lanka, 2010:303-308.

Alexopoulos C, Mims C, Blackwell M (1996). Introductory mycology. John Willey and Sons Inc. New York, 462-487 p.

Andrews JH (1992). Biological control in the phyllosphere.
Ann Rev Phytopathol 30:603-635.

Belanger RR, Benyagoub M (1997). Challenges and prospects for integrated control of powdery mildews in the greenhouse. Canad J Plant Pathol 19:310-314.

Boseewinket HJ (1980). The morphology of the imperfect states of powdery mildews (Erysiphaceae). Bot Rev 46:167-224.

Braun U, Cook TA, Inman AJ, Shin HD (2002). The taxonomy of the powdery mildew fungi, 13-55 p. In: Belanger RR, Bushnell WR, Dik AJ, Carver TLW (Eds.). The Powdery Mildews: A comprehensive Treatise. APS Press, St. Paul, MN.

Caruso C, Chilosi G, Leonard L, Bertin L, Magro P, Buonocore V, Caporal C (2001). A basic peroxidase from wheat kernel with antifungal activity. Phytochem 58:743-750.

Cohen R (1993). A leaf disk assay for detection of melons to Sphaerotheca fuliginea race1. Plant Dis 77:513-517.

Cook RJ, Baker KF (1983). The nature and practice of biological control of plant pathogens. APS, St Paul, MN, 539 p.

Derbalah AS, El Kot GA, Hamza AM (2011). Control of powdery mildew in okra using cultural filtrates of certain Bioagents alone and mixed with penconazole. Arch of Phytopathol PFL 44(30):2012-2023.

El-Kazzaz M, El-Assiuty EM, Badr MM, El-Zahaby HM, Gouda MI (2003). Effect of some plant extracts and essential oils on controlling sugar beet root rot disease caused by Sclerotium rolfsii Sacc. Proc $10^{\text {th }}$ Congress of Phytopathology, Giza, Egypt, December, 237-248 p.

Fang ZD (1998). The Research Method of Plant Pathogenesis. $3^{\text {rd }}$ Ed. Beijing, China Agriculture Press, 427 p.

Farag RS, Daw ZY, Hewedi FM, El-Baroty GSA (1989). Antimicrobial activity of some spice essential oils. J Protection 52(9):665-667.

Gilardi G, Gullino ML, Garibaldi A (2008). Effect of fungicides and biocontrol agents against powdery mildew of turnip. Commun Agric and Appl Biol Sci 73(2):21-29.

Gomez KA, Gomez AA (1984). Statistical procedures for agricultural research, $2^{\text {nd }}$ edition, John Wiley and Sons, New York, 680 p.

Hegazi MA, El-Kot GA (2010). Biological control of powdery mildew on zinnia (Zinnia elegans L.) using some biocontrol agents and plant extracts. J Agric Sci 2(4):221-229.

Jeong SI, Lim J, Jeon H (2007). Chemical composition and antibacterial activities of the essential oil from Abies koreana. Phytother Res 21:1246-1250.

Kiss L, Cook RA, Saenz GS, Cunnington JH, Pascoe I, Bardin M, Nicot PC, Takamastu S, Sato Y, Rosaman AY (2001). Identification of two powdery mildew fungi, Oidium neolycopersici sp. now and O. lycopersici, infecting tomato in different parts of the world. Mycol Res 105:684-697.

Kiss L (2003). A review of fungal antagonists of powdery mildews and their potential as biocontrol agents. Pest Manag Sci 59:475-483.

Konstantindou-Doltisinis S, Markellou Emilia. Kasselaki A-M, 
82

Fanouraki MN, Koumaki CM, Shmitt A, Liopa-Tsakalidis A, Malathrakis NE (2006). Efficacy of Milsana, a formulated plant extract from Reynoutria schalinesis, against powdery mildew of tomato (Leveillula taurica). Bio Control 51:375-392.

Krishna Kishore G, Pande S (2007). Evaluation of essential oils and their components for broad-spectrum antifungal activity and control of leaf spot and crown rot diseases in peanut. J Amer Soc Phytoathol 91(4):375-336.

Liang YC, Sun WC, Si J, Rőmheld V (2005). Effects of foliarand root-applied silicon on the enhancement of induced resistance to powdery mildew in Cucumis sativus. Plant Pathol 54:678-668.

Liu F, Zhuge YY, Yang CY, Jin SX, Chen J, Li H, Dal GH (2010). Control effect of some plant extracts against powdery mildew (Sphaerotheca fuligunea) and their stability study. Eu J Hort Sci 75(4):147-152.

Morsy SM, Grgham Elham A, Mohamed Gehad M (2009). Effect of garlic and onion extracts or their intercropping on suppressing damping-off and powdery mildew diseases and growth characteristics of cucumber. Egypt J Phytopathol 37(1):35-46.

Moustafa, MSH, Adb-El-Shahid YA, Ez-Eldin I, Anwar HM (1990). Occurrence of acquired resistance to fungicides in Erysiphe cichoracearum, the causal organism of cucumber powdery mildew. Agric Res Rev 68:513-520.

Nawar HF, Kuti JD (2003). Wyerone acid phytoalexin synthesis and peroxidase activity as markers for resistance of broad beans to chocolate spot disease. J Phytopathol 151:564570.

Nuñez-Palenius HG, Hopkins D, Cantliffe DJ (2009). Powdery mildew of cucurbits in Florida. Hort Sci Depart, Florida Cooperative Extension Service, Institute of Food and Agricultural Sciences, Univ of Florida, Document HS1067, 9 p.

O'Brien RG (1994). Fungicides resistance in populations of cucurbit powdery mildew (Sphaerotheca fuliginea). New Zealand J Crop Hortic Sci 22:145-149.

Pernezny K, Maynard D, Stall WM (2002). Powdery mildew of vegetables. Plant Pathology Fact Sheet, Floridia Cooperative Extension Service, USA, $14 \mathrm{p}$.

Picton DD, Hummer KE (2003). Control of powdery mildew on leaves and stems of Gooseberry. Hort Technol 13(2):365367.
Pramanik MHR, Masayuki N, Toshiki A (2000). Effects of temperature and photoperiod on phytotoxic root exudates of cucumber (Cucumis sativus) in hydroponic culture. J Chem Ecol 26:1953-1967.

Rakhonde PN, Koche Mina D, Harne AD (2011). Management of powdery mildew of green gram. J Food Legumes 24(2):120-122

Rettinassababady C, Ramadoss N, Thirumeni S (2000). Effect of plant extract in the control of powdery mildew of blackgram (Erysiphe polygoni DC). Agric Sci Digest 20(3):193-194.

Romero D, Vicente A, Zeriouh H, Cazorla FM, FernándezOrtuño Torés, Pérez-Garcia (2007). Evaluation of biological control agents for managing cucurbit powdery mildew on greenhouse-grown melon. Plant Pathol 56:976-986.

Scarito G, Salamone A, Vito Zizzo G, Agnello S (2007). Use of natural products for the control of powdery mildew of rose plants. Acta Hort 751:251-257.

Scheurell SJ, Mahaffee WF (2000). Assessing aerated and nonaerated watery fermented compost and Trichoderma harzianum T-22 for control of powdery mildew (Sphaerotheca pannosa var. rosae) of Rose in the Willamette Valley, Oregon. Phytopathol 90(6 Supp):S69.

Shailbala (2011). Efficacy of some organic materials, bio-agent and fungicide against powdery mildew of okra caused by Erysiphe cichoracearum DC. Plant Dis Res 26(2):184.

Sheng YW, Pin FC, Shang TC (2005). Antifungal activities of essential oils and their constituents from indigenous cinnamon (Cinnamomnum osmpophloeum) leaves against wood decay fungi. Biores Technol 96:813-818.

Singh AK (2008). Efficacy of plant extracts for the control of powdery mildew of coriander (Coriandrum sativum L.). J Spices and Aromatic Crops 17(1):24-25.

Varma P, Gandhi SK (2007). Bioefficacy of some plant extracts and biocontrol agents against Alternaria solani and their compatibility. Plant Dis Res 22(1):12-17.

Whipps JM, Lumsden RD (2001). Commercial use of fungi as plant disease biological control agents: status and prospects, 9-22 p. In: Butt TM, Jackson C, Magan N (Eds.). Fungi as biocontrol agents: progress, problems and potential. CABI Publishing, Wallingford.

Zambonelli A, Bianchi A, Elbasini A (1996). Effect of essential oils on phytopathogenic fungi in vitro. Phytopathol 86:491494. 